\title{
Elmozdulások és törésvonalak Kelet-Közép-Európa térszerkezetében
}

\section{Dislocations and ruptures in the spatial structure of Central and Eastern Europe}

\author{
RECHNITZER JÁNOS
}

\begin{abstract}
RECHNITZER János: tudományos tanácsadó, MTA Közgazdaság- és Regionális Tudományi Kutatóközpont, Regionális Kutatások Intézete; 9022 Győr, Liszt Ferenc utca 10.; egyetemi tanár, Széchenyi István Egyetem; 9026 Győr, Egyetem tér 1.; rechnitzer.janos@sze.hu
\end{abstract}

KULCSSZAVAK: Kelet-Közép-Európa; térszerkezet; területi versenyképesség

ABSZTRAKT: Horváth Gyula munkásságából e tanulmány szerzője azokat a műveket emelte ki, amelyek a kelet-közép-európai országok térszerkezetével foglalkoznak. Ezek a publikációk inspirálták a szerzőt, hogy végiggondolja az elmúlt 10-15 év magyarországi kutatásaiból az erre a nagyrégióra vonatkozó elemzéseket. E tanulmányban értelmezi a térszerkezet fogalmát, lehatárolja a nagyrégiót, és két szinten végez értékelést. A térszerkezet vonatkozásában jelzi a lassú elmozdulásokat, a versenyképesség esetében a számottevő különbségekre hívja fel a figyelmet. A nagyrégió területi sajátosságaiból kiemeli a versenytér fokozatos kialakulását, a fővárosok egyre erőteljesebb erőforrás-koncentrációját. Kitér a regionális központok kapcsolatainak hiányosságára, a területi tervezésben pedig az együttműködéseket sürgeti. Hangsúlyozza, hogy a magrégiókban a járműipar vált a meghatározó gazdasági szektorrá, ami növelheti e térségek kitettségét. Megállapítja, hogy Kelet-Közép-Európa összességében nem válik új fejlődési övezetté Európában, ám a fővárosok, s néhány regionális központ és környéke sikeres felzárkózást folytathat, miközben a nagyrégióban a területi különbségek látványosan növekednek.

János RECHNITZER: scientific advisor; Institute for Regional Studies, Centre for Economic and Regional Studies, Hungarian Academy of Sciences; Liszt Ferenc utca 10., H-9022 Györ, Hungary; professor, Széchenyi István University; Egyetem tér 1., H-9026 Györ, Hungary; rechnitzer.janos@sze.hu

KEYWORDS: Central and Eastern Europe,;spatial structure; regional competitiveness

ABSTRACT: Gyula Horváth's works about Central and Eastern European countries and their spatial structure inspired the author to review those Hungarian studies of the past 10-15 years which take this big region as their main focus. The study interprets the concept of spatial structure, delimits the boundaries of the region and carries out a two-level evaluation. It also indicates the slow changes occurring in the spatial structure and highlights the considerable differences between its different parts in terms of their competitiveness. Finally, it underlines the emergence of the competitive space and increasing resource concentration in the country capitals as the region's major spatial characteristics. The study also discusses the communication deficiencies between the regional centers and, thereby, urges for an increased

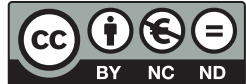


cooperation in spatial planning. It highlights how the automotive industry's dominance in the core regions can increase the area's risk of exposure. The paper's main conclusion is that Central and Eastern Europe will not become a new development zone of the continent and, while the country capitals and certain regional centers with their surroundings might catch up successfully, intra-regional disparities increase with an enormous pace.

\section{Bevezetés}

A téma feldolgozását az inspirálta, hogy emléket kívánunk állítani Horváth Gyula professzornak, aki a regionális kutatásokban kiemelkedő aktivitással irányította a figyelmet a címben jelzett nagyrégióra.

A gazdag Horváth-életmüben külön fejezetet kell szánni a Kelet-KözépEurópát érintő kutatásoknak. Munkássága korai szakaszának összefoglaló monográfiájában, Az európai regionális politika (1998) című művében még nem fogalmazza meg a nagytérségre vonatkozó kutatásainak eredményeit, ellenben megjelennek a regionális politika főbb alkotóelemei, alkalmazásuk módszerei, kiemelten a decentralizáció, s annak intézményi keretei. Ebben a szemléletben született az első, általunk kiemelkedőnek ítélt tanulmány a nagyrégió országainak területi szerkezetéről, s az egyes országokban a regionális szint kompetenciájának értékeléséről (Horváth 2000a, 2000b), valamint az átmenet területi hatásainak bemutatásáról (Horváth 2002, 2004).

Az ezredfordulón indította el Horváth Gyula a Kárpát-medence régiói című sorozatát, amely nemcsak kiemelkedő tudományszervezési feladatot jelentett, hanem mérföldkőnek számít e makrorégiók történeti, gazdasági, társadalmi, s egyben regionális tudományi feldolgozásában. A 15 kötetre tervezett sorozat (ebből 13 régiómonográfia már megjelent) egységes tematikával készült, bemutatva mindazon ismérveket és tényezőrendszereket, amelyek e makrorégiót - alkotóegységein, a régióin keresztül - jellemzik (Horváth 2005, 2010).

E nagy ívű munkálatok vezették el tisztelt barátunkat ahhoz a ponthoz, hogy kitekintsen a kelet-közép-európai országegyüttes egészére, s sorban születtek meg az irányt adó tanulmányai a nagytérségről. A témakörök felsorolásával csupán jelezni kívánjuk a kutatási irányok sokszínűségét, egyben a további elemzésekre irányuló inspirációt. Így többek között a régióközpont funkcióinak értelmezését (Horváth 2007a), a regionális intézményrendszer kialakítását (Horváth 2007b, 2012a), a regionális egyenlőtlenségek bemutatását (Horváth 2009), a területfejlesztés működési rendszereinek és keretfeltételeinek vázolását (Horváth 2012b), a kutatás-fejlesztés és a területi fejlődés kapcsolatát (Horváth 2013b, 2014) tekintette át munkássága során Horváth Gyula. S nem feledkezett meg a nagytérség egyes országaiban a regionális tudomány kutatási irányainak és szervezeti kereteinek bemutatásáról sem (Horváth 2013a). Nem élvezhette tisztelt barátunk az angol nyelvű összefoglaló munkájának sikerét, amelyet Kelet-Közép-Európa helyeiről és tereiről írt, s neves külföldi kiadónál 
jelentetett meg (Horváth 2015a). Poszthumusz műként került kiadásra a keletközép-európai 8 uniós tagország 65 régióját egységes szempontok alapján feldolgozó kötete, amely a Horváth-életmű utolsó kiemelkedő publikációja, egyben a nagyrégió hazai és külföldi kutatói, elemzői számára hosszú évekre eligazítást nyújtó összefoglalás (Horváth 2015b).

Igényes és következetes életmű tárul tehát elénk, amelyben az országegyüttes sokoldalú feldolgozására került sor, olyan kiapadhatatlan szellemi forrás, amely nemcsak a kutatók, elemzők újabb generációinak adhat eligazítást, hanem a regionális tudomány megújításához is irányokat mutat. S talán e nagyrégió politikai döntéshozói számára szintén segítséget nyújt az együttmüködési szférák meghatározásában, a közös fejlesztési célok kijelölésében.

Tanulmányunkban kiindulásként Kelet-Közép-Európa lehatárolását kíséreljük meg és foglalkozunk a térszerkezet fogalmával. Felvázoljuk a nagytérség térstruktúrájára irányuló fontosabb hazai kutatások eredményeit, majd általunk végzett elemzés segítségével a versenyképesség leírását adjuk meg NUTS 2 szinten. S végül összefoglaljuk azokat a területi sajátosságokat, amelyek az eddigi hazai kutatások alapján - s egyben a Horváth-életmű e részének áttanulmányozása után - Kelet-Közép-Európa területi folyamatairól, térszerkezetéről, annak jövőbeli alakulásáról állapíthatók meg.

\section{A vizsgált térség}

Mit is tekintünk Kelet-Közép-Európának? Ennek az európai nagytérnek a meghatározására számos elméletet fogalmaztak meg (Szűcs, Hanák 1986), igényes feldolgozások születtek az országegyüttes korábbi területi sajátosságainak feltárására. Értékes elemzéseket olvashatunk a rendszerváltozás utáni társadalmi és gazdasági szerkezetének alakulásáról (Ehrlich, Révész, Tamási 1994). Az elemzések a területi sajátosságainak bemutatásával (Horváth 2000b; Illés 2002), a településhálózat rendszerével, meghatározó centrumainak sajátosságaival szintén foglalkoztak (Csapó, Balogh 2012; Csomós 2011; Enyedi 2010; Horváth 2007a; Tagai 2010). Olvashatunk publikációkat a strukturális politikák alakulásáról (Fábián 2011), egyes országok területi politikájáról, eszközeiről (Mezei 2006; Rechnitzer, Smahó 2011), a gazdasági és ipari szerkezet átalakításáról, modellezéséről (Kuttor 2012; Lux 2009; Molnár 2012), régiói versenyképességének meghatározásáról (Lengyel 2012). Az utóbbi években ugrásszerủen megnőtt a nagytérséggel foglalkozó hazai vizsgálatok és tanulmányok száma, ami egyértelmủen arra utal, hogy ez az országegyüttes a szakmai érdeklődés fókuszába került.

A tanulmányok jelzik azt is, hogy a nagytérség lehatárolásában jelentős különbségek, eltérések vannak. A kutatások egyik csoportja az 1991-ben alakult Visegrádi Együttműködés (V4) országaira (Csehország, Lengyelország, Magyarország, Szlovákia) fókuszál, ezt többen kiegészítik Ausztriával, s így jelenítik 
meg Közép-Európát. Más elemzések még hozzákapcsolják a nagytérséghez Németország keleti tartományait, esetleg Bajorországot, a Nyugat-Balkánhoz köthető (Horváth 2010) Szlovéniát, valamint Romániát, így már egy szélesebb Kelet-Közép-Európáról beszélnek.

Számunkra ez a tágabb felfogás volt szimpatikusabb. Egyrészt az országok többsége lényegében közel egy időben csatlakozott az Európai Unióhoz, vagy hamarosan csatlakozni fog. Másrészt magyar kitekintésből szemlélve ezen országegyüttes történelmi alapjaiban számos azonosságot fedezhetünk fel, és a 20. században az egyes országokat, s ezzel az egész nagytérséget a gazdasági, a kereskedelmi és a történelmi-kulturális kapcsolatok millióinak szövedéke fonja egybe. Továbbá, korábban azonos politikai berendezkedés jellemezte Európa e részét, s annak közel egy időben történő felszámolásában szintén azonosságokat tapasztalunk. S végül, de nem utolsósorban, sajátos geopolitikai helyzet jellemzi ezeket az országokat, hiszen Nyugat és Kelet között találhatók, s a változó nagypolitikai hangsúlyokban ezt a pozíciójukat korábban és a jövőben is sajátos módon érvényesíthetik.

Vizsgálatunkban tehát egy nagyobb, intenzívebben összetartozó, fejlődésében és azok mozgatóelemeiben megegyező országegyüttesre fókuszálunk, s így Kelet-Közép-Európának tekintjük Németország keleti és déli tartományait, Ausztriát, Lengyelországot, Csehországot, Szlovákiát, Magyarországot, Szlovéniát, Romániát. Bulgáriát. Ebben az országcsoportban ${ }^{1}$ - mint európai nagytérségben - teszünk kísérletet a térszerkezet felvázolására, változásainak regisztrálására.

\section{A térszerkezetről}

Szabó Pál kiváló tanulmányában (2009), majd habilitációs értekezésében (2015) foglalja össze a térszerkezettel kapcsolatos hazai értelmezéseket. Három megközelítést ad a fogalom használatához. Az első esetben az elemek (alkotótényezők) és azok térbeli elrendeződése tekinthető a meghatározás alapjának, míg a másik értelmezési körben a tér alkotóelemei alapján történik a kategorizálás. $\mathrm{S}$ végül a harmadik csoportba azokat a vizsgálatokat sorolja, ahol a térelemek egymáshoz való viszonyítása, azaz a szerkezetek eltéréseiként, azok eloszlásaiként értelmezett térbeli formációk elemzése, leírása kerül a fókuszba.

A viszonyításhoz, azaz a térbeli fejlődés eltéréseinek illusztrálásához köthetjük a szerző által említett másik csoportosítást is, amely földrajzi és regionalista (területfejlesztési) szemléletben készülhet. Földrajzi szemléletnek tekinti Szabó a régió és a térszerkezet összekapcsolását, vagyis a hálózati elemek (közlekedés, településhálózat, infrastruktúra-rendszerek) általa szabdalt, alakított földrajzi tereinek leírását. A regionalista szemléletűekhez azokat sorolja, akik a lehatárolásokat a térszerkezeti egységek közötti mennyiségi és minőségi differenciálódás alapján végzik el, majd ennek alapján határolják le az egyes térbeli 
fejlődési irányokat. Az egy országra vonatkozó elemzések az adminisztratív egységekre (település, kistérség, megye, tervezési-statisztikai régió) is irányulhatnak, amelyek aztán különféle típusú, jellegủ térbeli formációkban jelenhetnek meg. Ezeket közös jellemzőik szerint különíthetjük el, más - éppen az adott elemzések által kimutatott - egyedi térbeli alakzatoktól. Az elkülönítés egyben összevetést is jelent, egy vélt vagy valós fejlettségi szinthez képest, amely a térbeli szerkezetekre vonatkozó megállapításoknak képezheti az alapját.

Véleményünk szerint a regionális szemlélet arra irányul, hogy a térbeli fejlődési irányokat határozzuk meg. Kijelöljük azokat az folyamatokat, tényezőrendszereket, amelyek alapján leírható egy országrész, ország vagy éppen országegyüttes, sőt, akár egy kontinens fejlődési sajátossága. Megjeleníthetők - tanulmányozandó ismérvek alapján - a térbeli megoszlások, differenciák, s ezzel irányokat szabhatunk a fejlesztési beavatkozásokhoz, a térbeli szerkezetben kívánatosnak tekintett politikai, ideológiai célok kijelöléséhez, majd az azokhoz rendelhető eszközök és intézmények meghatározásához.

Térszerkezeten országok, országegyüttesek (csoportok) területi beosztásától független, döntően gazdasági, társadalmi, településhálózati tényezők vagy azok valamilyen kombinációja alapján jól lehatárolható, más és más fejlődési pályán lévő, egymástól is elkülöníthető területi egységek kijelölése, meghatározása értendő (Rechnitzer, Smahó 2011). Az azonos karakterek - mint adott térben elkülönült szerkezeti, szervezeti, intézményi egységek - egyedi, sajátos kombinációkat alkotnak, amelyek valamilyen ismérvrendszer szerint jól jellemezhetők, egyben minősíthetők is. Ezeket - egy vagy több időszakban - többségében azonos gazdasági, társadalmi és településhálózati tényezők jellemeznek és határoznak meg. A térszerkezet egységei tehát - mint az adott fejlődési pálya állapota - körülírhatók, valamilyen elvárások alapján (pl. fejlődés, elkülönülés, koncentráció) minősíthetők, s azok megváltoztatására területpolitikai célok - a jövőben kívánt fejlődési irányok, a helyzetük és állapotuk átalakítása, a beavatkozások jellege, módja - határozhatók meg.

Térszerkezeti egység az azonos vagy több ismérvben azonosnak tekinthető (egymáshoz kapcsolható), egyben determináló gazdasági, társadalmi, településhálózati tényező koncentrált megjelenése. A térnek több rétege, mezője van, amelyek egymásra rakódnak, egymást erősítik vagy éppen gyengítik (Rechnitzer, Smahó 2011). A térmezők sajátosságai, eltérései a különböző területek földrajzi adottságaitól, az egyes mezők általános gazdasági, társadalmi és politikai megítélésétől vagy éppen támogatottságától függenek. Így a térszerkezet alakításában játszott szerepük más és más lehet. A területi politika egyik célja éppen az, hogy ezeket a térmezőket befolyásolja, azok alakításához hozzájáruljon.

A különféle jellegű mezők a térben egymásra rakódnak, de hatásuk, erősségük az egyes térpontokban (pl. településekben, összetartozó térségekben) eltérőek lehetnek. Egyesek sűrűsödnek, koncentrálódnak, mások kevésbé vannak jelen. Közben a mezők egymásra hatnak, egymást építik, vagy éppen rombolják, gyengítik a többieket. A relációk és viszonylatok a mezők között időben változ- 
nak. Egy adott időmetszetben egyesek felértékelődnek, továbbiak szunnyadnak vagy korábbi szerepüket elveszítik, aztán egy következő időmetszetben - más fejlődési viszonyok között - újra előjönnek, már újabb megvilágításban, összefüggésben, vélhetően egy másik mezővel alkotnak kapcsolatot, azokra hatva szinergiákat teremtenek. A térszerkezet egészének változása a mezők átrendeződéséből következik, vagy abból, hogy az egyes mezők értékelésében új szempontok, összefüggések jelennek meg.

A térszerkezet-elemzések célja tehát annak megállapítása, hogy a vizsgált nagyobb területi egység - lehet ország vagy országok együttese - milyen közös jellemzőkkel rendelkező egységekből, összetartozó ismérveket mutató, térben is - valamilyen szempont szerint - lehatárolható alkotókból áll, s ezek a jövőben milyen irányban fejlődhetnek, változhatnak. A cél a fejlesztés orientálása, annak szemléltetése, hogy milyen lehetséges beavatkozások szükségesek a felrajzolt állapotok megváltoztatására vagy módosítására.

Ennek megfelelően a térszerkezeti elemzés lehet a jelen állapotának regisztrálása vagy a jövőbeli kívánt helyzet, fejlődési szint kijelölése, előrevetítése. Az elemzések a területi politika eszközeiként értelmezhetők, a beavatkozások irányainak kijelölésére, meghatározására, ennek következtében a térszerkezet-vizsgálatok a horizontális fejlesztéspolitikának az egyik elemzési eszközeként használhatók. Így a térszerkezeti típusok mint fejlődési szintek vagy térbeli, elkülöníthető sajátosságok válnak alakíthatóvá. A fejlettnek tekintett állapottól haladhatunk a fejletlen vagy az adott viszonyok között elmaradott, periferikus minősítés felé. Ennek fokozatai, a kijelölt területi egységeknek a minősítés létráján való elhelyezése az elemzések, az értékelések és a területi politikai célok függvényében változhatnak.

S végül alapvető kérdés az egyes térszerkezeti egységek, azaz fejlődési típusok kijelölési módja, annak módszertani bázisa. Számtalan elemzési módszer ismert vagy éppen kidolgozás alatt áll a területi szintek minősítésére, azok állapotának regisztrálására, egymáshoz viszonyításukra. Leegyszerűsítve két úton indulhatunk el.

Az egyik a fejlettséget kifejező mutatók alapján történő besorolás, ekkor egy vagy több közismert tényezővel dolgozva (ezek döntően a területi gazdasági potenciál mérőszámai, pl. az egy lakosra jutó GDP) lehatároljuk a területi egységeket, majd további ismereteink alapján a kialakult képet finomítjuk, pontosítjuk. A másik megoldás a területi egységeket jellemző különféle gazdasági, társadalmi, településhálózati mutatóknak - lényegében a mezők jellemzőinek - összegyüjtése, s azok elemzése összetett értékelési módszerek alapján (pl. többváltozós elemzések, előrevetítési eljárások, szimulációs technikák stb.).

Mindkét irány sikerrel alkalmazható, sőt a kettő kombinációja is megoldást kínálhat. Nem feledhetjük, hogy a térszerkezet-elemzés célja a fejlesztés orientálása, a lehetséges irányainak kijelölése, így a területi analízis kellő összegzési tapasztalatot, kreatív problémafeldolgozást és az adott területi egységek ismeretét kívánja meg. A megjelenítés módja a térképi ábrázolás, de ez csak ahhoz 
segít, hogy térben is el tudjuk „helyezni” a megállapításokat, amelyeket - mint térszerkezeti elemeket - kellő pontossággal és a fejlesztést támogató összefüggések alapján írunk le.

\section{Kelet-Közép-Európa az európai térszerkezetben}

Európára vonatkozó térszerkezeti modellek a múlt század nyolcvanas, kilencvenes éveiben jelentek meg, azzal a céllal, hogy illusztrálják az európai tér fejlődési irányait. Az ábrázolások és a nagy ívű térségi lehatárolások a centrum-periféria modell klasszikus elvein nyugodtak. A centrumtérségek - melyeknek csomópontjai a nyugat-európai nagyközpontok voltak - a gazdasági erőforrásokat és a politikai döntéshozás minden intézményét is koncentrálták, s ebben a jól lehatárolt térben történt a gazdaság megújítása, az innovációk tömörülése. Így jött létre a Kék banán ${ }^{2}$ mint az európai nagycentrumok - történetileg is értelmezhető - gazdasági övezete, amely megjelenítette Nyugat-Európa domináns centrumait s azok vonzástérségeit (Brunet 1989). Ennek az övezetnek a kiterjesztése történt meg a modellek átgondolása során, hiszen részben a megacentrumok agglomerációs területeivel, új központok beépítésével formálódó fejlődési zóna már Londontól és Párizstól kezdve a Ruhr-vidéken át egészen Milánóig fogta át Európa meghatározó központjait és azok befolyásolási tereit (Kunzmann 1992).

A fejlődési övezetek felvázolása folytatódik a kilencvenes években. Megjelenik Dél-Európa fejlődési zónája, amely Barcelona, Lyon, Marseille, Genova, Milánó, Velence, Róma nagyközpontokat és agglomerációs térségeiket foglalja magában. Ezt a sajátos funkciókkal rendelkező (szolgáltatásorientáció, turizmus, erősödő lokális gazdaságok, új típusú termelési rendszerek és térségi kapcsolatok) fejlődési tengelyt nevezték a Dél Északjának, Európai napfényövezetnek (Sunbelt) vagy Második banánnak (Lever 1995).

Mindezek mellett felrajzolható volt az európai high-tech körgyürü is, amely Glasgow-ból indulva Barcelonán át Milánót érintve Bécset belefoglalva - megszakadva Közép-Európában - Malmőnél kerül vissza a kiinduló helyzetéhez. Itt jelenik meg elsőként Bécs mint az akkori Európa utolsó állomása, amelyen túl már a periferikus térségek, így Kelet-Közép-Európa található, a maga ismeretlenségével, feltáratlanságával (1. ábra).

A kilencvenes évek elején a regionális folyamatok egyértelműen jelezték, hogy a kelet-közép-európai országok gazdasági integrációja óhatatlanul regionális integrációs formát ölthet (Enyedi 1996). A létrejött Visegrádi Együttmüködés országainak gazdasága és intézményei elvben alkalmassá válhattak gazdasági integrációra, ezek a hatások egyidejủleg területi integrációs folyamatokat is megindíthattak, nemcsak a szomszédos akkori Európai Közösség országaival, hanem keleti, posztszocialista országokkal is. Ennek az integrációs folyamatnak bizonyos jegyei felismerhetők voltak a kelet-közép-európai orszá- 
1. ábra: Európa térszerkezeti modellje a kilencvenes években Spatial model of Europe in the 1990s

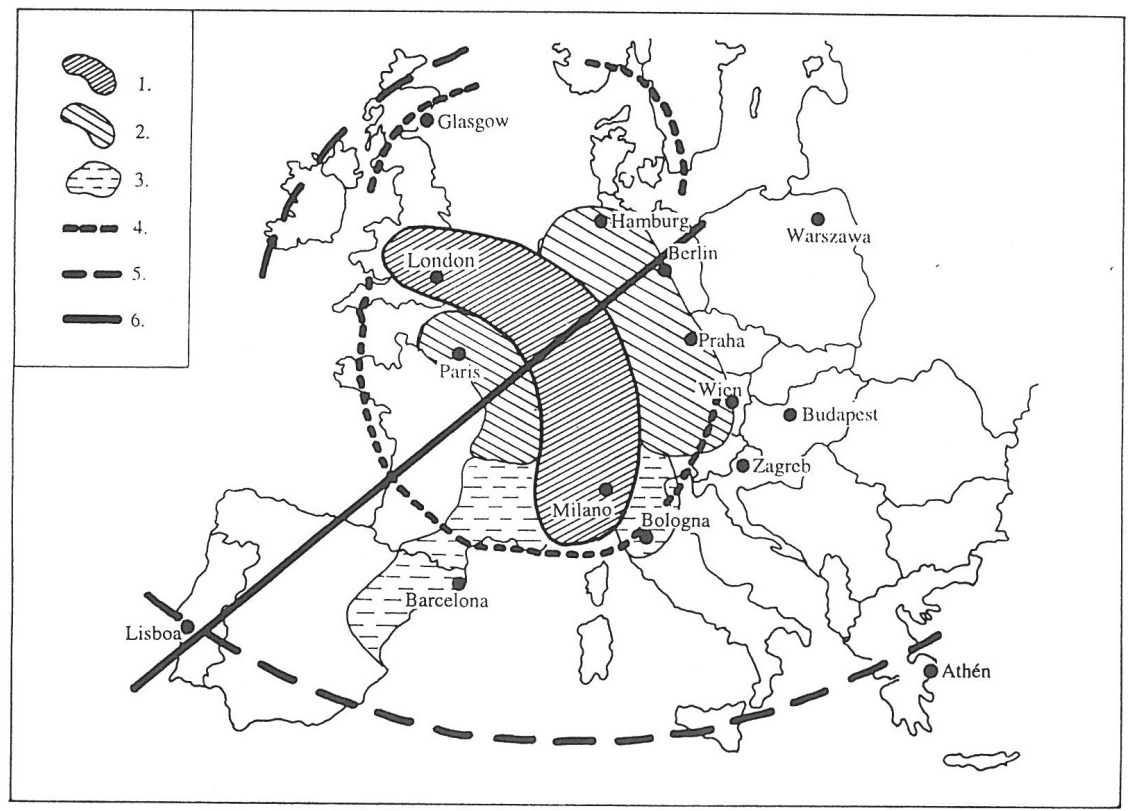

Jelmagyarázat: 1. Kék banán. 2. A Kék banán kiterjedése, az indukált övezetek. 3. Dél Északja (sunbeltövezet). 4. High-tech körgyürü. 5. A fejletlen régiók körgyürüje. 6. Problémarégió.

Forrás: Rechnitzer 1998, 67.

gokban ${ }^{3}$ kirajzolódó makroregionális struktúrákban (Gorzelak 1996; Rechnitzer 1998; Rechnitzer, Smahó 2011), amelyek számos sajátosságot, egyben bizonyos fejlődési irányokat is mutattak (2. ábra).

A makroregionális szerkezetben a városrégiók a kapcsolatok megtestesítői. Magyarországon a budapesti agglomeráció, Csehországban Prága és Brno agglomerációja, Lengyelországban Varsó, Poznan, Wrocław, Gdańsk, Krakkó, Szlovákiában Pozsony és térsége, valamint Kassa régiója. A nyugat-kelet fejlettségi lejtő az országokban már akkor érvényesült, azonban a keleti határokhoz közelítve megtört és lépcsőként egy másik, már az előzőnél jóval kedvezőtlenebb fejlettségi szintben folytatódott. Így lényegében a kelet-közép-európai térség országainak nyugati határövezeteit tekintették a tanulmányok a kibontakozóban lévő makroregionális, határon átnyúló együttműködések megalapozóinak, míg a keleti régiókat az igazi perifériának, a felzárkózás gyenge esélyével.

Az elemzések Kelet-Közép-Európa nyugati fejlődési zónáját mint a „Kelet-közép-európai banánt (bumerángot)", a Gdańsk-Poznań-Wrocław-Prága-Brno-Pozsony-Bécs-Budapest nagyvárosok övezetében látták. Itt a fővárosok és a jelentős ipari, igazgatási központok koncentrálódtak, s azok szervezetei közvetlen kapcsolatban álltak az osztrák és német gazdasággal, nagy és közepes befektetők ezekben a térségekben telepedtek meg, továbbá a Nyugatról ide irányuló szolgáltatási és be- 
2. ábra: Kelet-Közép-Európa térszerkezeti modellje a kilencvenes években Spatial model of Central and Eastern Europe in the 1990s

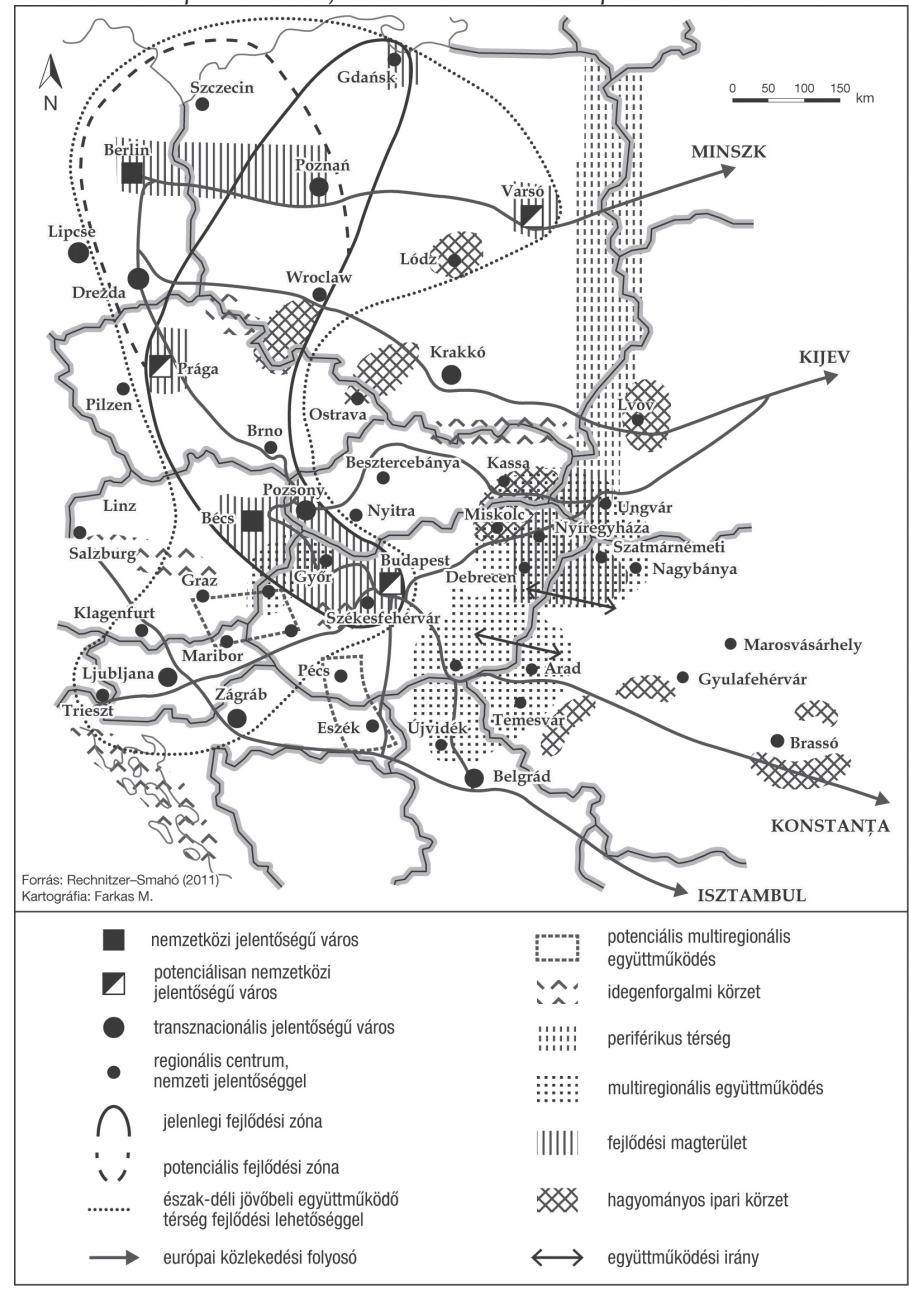

Forrás: Rechnitzer, Smahó 2011, 55. nyomán Szabó, Farkas 2014, 74.

vásárlóturizmus fogadására is ezek a központok voltak alkalmasak a kilencvenes évek közepén. A másik sajátosság, hogy ebben a zónában találkoztak elsőként a relatívan fejlett, döntően ipari potenciállal és kedvezőbb infrastruktúrával rendelkező kelet-közép-európai térségek a viszonylagosan fejletlennek tekinthető osztrák és német régiókkal. Ennek következtében természetes versenyhelyzet alakul ki a térségek között, ami nemcsak az osztrák, német relációra volt érvényes, de az egyes országok intraregionális viszonyaira is hatott. Ezen azt értjük, hogy a külföldi tőkebeáramlás következtében ezekben a nyugati vagy a fővárosra épülő régiókban a gazdaság gyorsabb - s mondhatni sikeresebb - átalakuláson 
ment át, így az egyes országokon belüli nyugat-keleti vagy főváros-vidék megosztottság nem csökkent, hanem fokozódott.

A „Kelet-közép-európai banán” (más megnevezésekben bumeráng) két potenciális fejlődési övezetet, kiterjesztést indíthat vagy indított el. Az egyik zóna fókusza Prágát és a volt kelet-német ipari nagyvárosokat (Berlin, Lipcse) - kapcsolódva Berlinnel - foglalja magába, majd Poznańnyal kanyarodik vissza a cseh fóváros térségéhez. Jelezve azt, hogy látványosabban formálódik a Berlin-Varsótengely, amely nemcsak új közlekedési és kommunikációs folyosóként (II. közlekedési korridor) szolgálhat a jövőben - Minszk és Moszkva irányában -, hanem innovációs tengelyként is számba vehető. Ez egyben súlyponteltolódást eredményezhet majd a kelet-közép-európai térszerkezetben, hiszen jelentős árumozgásokat „csábíthat át”, valamint új gazdasági irányokat jelölhet ki, ami a korábbi térkapcsolatok leértékelését, azok eltolódását eredményezheti, s egyben a térszerkezet átrendeződését is kiválthatja. ${ }^{4}$

A „Kelet-közép-európai banánnak” egy további potenciális kiterjesztése már észak-déli együttműködési irány, amelyben összekapcsolódhat az Adriaitengerpart az Északi- tengerrel. Ebben a feltételezett bővülésben már határozottabban érvényesülhet a Berlin-Varsó-tengely, de egyben aktívabbá válhatnak Szlovénia, Horvátország, illetve Ausztria keleti és déli tartományai is. A térszerkezet sajátosságai miatt feltételezheto", hogy Kelet-Közép-Európa északi és délnyugati jövőbeli fejlődési térségeinek egybefüződése a Prága-Brno-Bécs-Pozsony-Győr-Budapest-tengely mentén jöhet létre. Itt formálódhat ki az a gazdasági és térszerkezeti fordítókorong (Kelet-közép-európai gomba), amely Kelet-Közép-Európa jövőbeli megújítási övezeteit az elkövetkező évtizedekben akár Kelet-Európa (döntően Kelet-Szlovákia, illetve Ukrajna) és a Balkán (többségében Románia, Szerbia, Bulgária) irányába egybefüzheti, közvetítve a tőkét, a tudást és az innovációkat azok régiói és nagyközpontjai felé.

A jelenlegi és a jövőbeli fejlődési zónákon kívül különböző sajátosságokkal rendelkező átmeneti térségek is jelen voltak Kelet-Közép-Európában a kilencvenes években. Ezek egy része a tradicionális ipari körzetek, az átalakuló mezőgazdaság térségei vagy a hegyvidékeken az idegenforgalom által megújításra érdemes terek, a határ menti együttműködéseket alkalmazni szándékozó nagyvárosok, továbbá a tradicionális perifériák. Kirajzolható volt a „keleti fal”, amely megtörte a fejlettségi lejtőt, és az országegyütttesnek a keleti - Fehéroroszországgal és Ukrajnával érintkező - periferikus határtérségeit foglalja magában. Ezekben a többségében mezőgazdaságra alapozott vidéki térségekben a falusi és a kisvárosi településhálózat, kedvezőtlen - az adott országok átlaga alatti - infrastrukturális ellátottság volt a jellemző. A többi vidéki régióban a megújítást szolgáló belső erőforrások még szegényesek voltak, a külföldi tőke érdeklődése elenyésző, a foglalkoztatási és társadalmi feszültségek éleződtek. A periferikus helyzet számtalan hátránya mellett előny az, hogy a posztszovjet térségek kvázi fejlett „nyugati” régiókkal érintkeznek, így lehetőség kínálkozott az erőforrások egyes elemeinek aktivizálására, a kapcsolatok újabb tereinek létrehozására. A „keleti fal” lebontását azonban tartó- 
san akadályozta a korszerütlen és szűk keresztmetszetủ közlekedési (és határkapcsolati) infrastruktúra, a posztszovjet államok lassan formálódó intézményrendszere, az Európai Unió keleti határainak fokozódó védelme, a feketegazdaság elburjánzása, a kimondottan rossz közbiztonság.

\section{Kelet-Közép-Európa régióinak versenyképessége}

Az általunk értelmezett Kelet-Közép-Európa nagytérség régióinak (NUTS 2) versenyképességét kutattuk. Célunk az volt, hogy megadjuk egyrészt azokat a tényezőket, gazdasági, társadalmi, intézményi faktorokat, amelyek determinálják a vizsgált nagytérség egészét, régióinak egymáshoz viszonyított szerkezetét. Másrészt a magyar régiók pozicionálásával ajánlásokat kívántunk megfogalmazni helyzetünk javítására, egyben a versenyképességünk megítélésére, majd erősítésére.

A versenyképesség elméleti modelljeinek értékeléséhez, valamint az ezekkel kapcsolatos kutatásokhoz annyiban járultak hozzá elemzéseink, hogy sikerült a meglévő modellbe új elemeket is beépíteni (Lengyel 2000, 2012). A munkatermelékenység és foglalkoztatás klasszikus alapkategóriáit finomítottuk, s ennek következtében a kutatás-fejlesztési, a humán tőkét megjelenítő, a működő tőkét megragadó alaptényezők mellett beépültek a modellbe a társadalmi tőkeelemek, valamint a traded szektorra (exportra termelő ágazatok) vonatkozó paraméterek.

Nyolc ország NUTS 2 egységeit hasonlítottuk össze, ami 93 régiót jelent, az elemzésekhez 25 változót ${ }^{5}$ vettünk alapul, amelyeket különféle matematikaistatisztikai módszerekkel értékeltünk.

A versenyképesség tényezőit, így a munkatermelékenységet és a foglalkoztatást elemezve megállapítható, hogy a nagytérség erősen differenciált, abban jól elhatárolható törésvonal rajzolódik ki. Az elkülönülés általában azzal jellemezhető, hogy a fejlett nyugat-európai piacgazdaságok (Németország, Ausztria) és a felzárkózó kelet-közép-európai térség régiói határozottan és egyértelműen elválnak egymástól. Az előbbieknél a magas szintű foglalkoztatás nagy termelékenységgel párosul, míg a másik csoportban pontosan fordítva, az alacsony szintű foglalkoztatás kisebb termelékenységgel jár együtt.

A nagytérség erősen megosztott, a vizsgálatok megerősítik az ismert nyugat-keleti különbségeket, a volt szocialista országok esetében a fővárosok erőforrás-koncentrálását, a régiók közötti nagy különbségeket, így viszonylag kis számban ismerhetünk fel fejlődési zónákat (egybefügg”, azonos fejlettségű régiók vonulatát), szemben a gyengén fejlett, döntően periferikus régiók nagyobb tömbökben való megjelenését (3. ábra).

A magyar régiók a nagytérségben a volt szocialista országok régióihoz képest nincsenek kedvező helyzetben. Csak a fóvárost magába fogadó Közép-Magyarország és a Nyugat-Dunántúl esetében jelezhetünk értékelhető versenyképességet, a többi régió erősen leszakadt, a gyenge versenyképességü kategó- 
3. ábra: Kelet-Közép-Európa régióinak versenyképessége Competitiveness of the Central and Eastern European regions

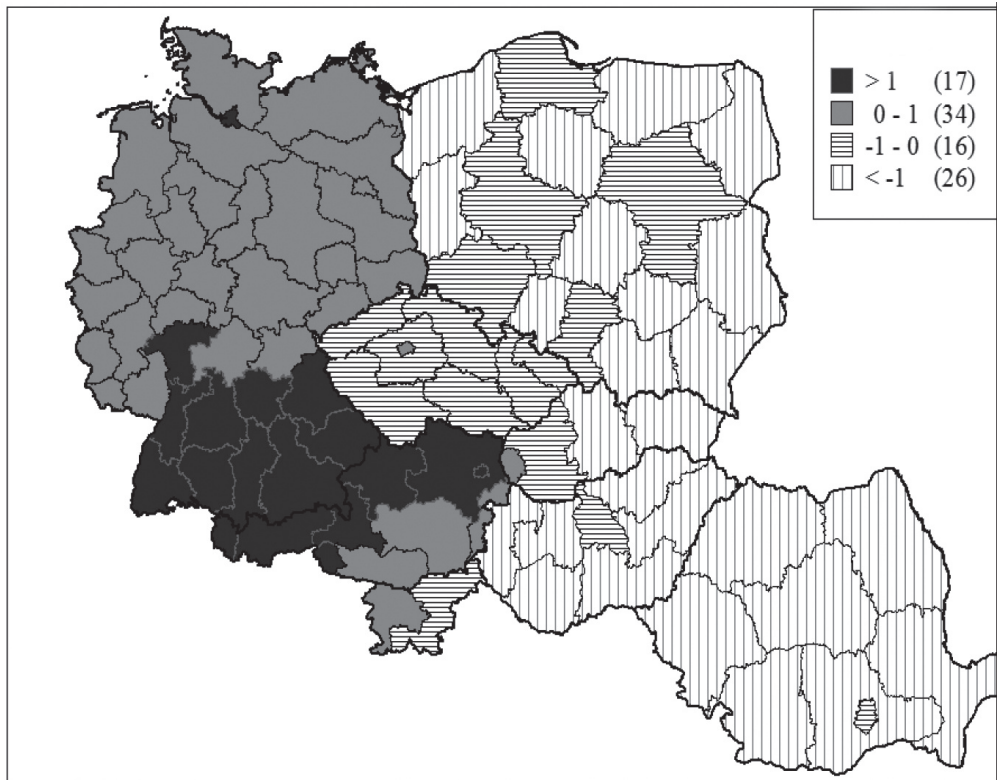

Forrás: Lengyel, Rechnitzer 2013, 113.

riába sorolódott. Ezt támasztja alá azon vizsgálat is, amikor a versenyképességi főkomponenst - mint az elemzett tényezők koncentrált kifejezőjét - összehasonlítjuk az egy lakosra jutó GDP-vel, s a kapcsolatokat kétdimenziós ábrába rendezzük (4. ábra).

A nagytérség megosztottsága még látványosabb, még egyértelműbb, hogy Kelet-Közép-Európában jelentős fejlődésbeli különbségek alakultak ki. A törésvonalat (a versenyképesség átlagos értékét) a fentebb jelzett német és osztrák régiókon túl csak a prágai és a pozsonyi régió tudta átlépni a volt szocialista országok területi egységei közül. ${ }^{6}$ A magyar fóváros csak átbillen az európai régiók átlagos értékei felett az országos szinten kiemelkedő versenyképességével és kedvezőbb fajlagos GDP-jével. A Nyugat-Dunántúl és a Közép-Dunántúl régió átlaghoz közelítő egy főre jutó GDP-ellátottsága ugyan még érzékelhető, de alacsony a versenyképessége, mindez súlyozottabban érvényes a többi magyar régiónál, amelyek az erősen leszakadó tömb alján, azok sűrüjében helyezkednek el.

A további vizsgálatok - a versenyképességre ható tényezők belső elemzései - megállapították, hogy két faktor határozza meg a régiók helyzetét a versenyképességben. Az egyiket nevezzük humán tőkének - ez a tényező a munkaerő fejlettségét, a munkaerővonzás képességét és a szabadalmak meglétét foglalja magában -, amely erősen megosztja a nagytérséget, annak differenciálásában árnyaltabb képet nyújtva. A magyar régiók közül Nyugat- és Közép-Dunántúl közelebb állnak a határmezsgyéhez közelítő cseh és lengyel régiókhoz. A 
4. ábra: A versenyképességi főkomponens és a gazdasági fejlettség (GDP/lakos) kapcsolata Relationship between competitiveness main component score and economic development (GDP per capita)

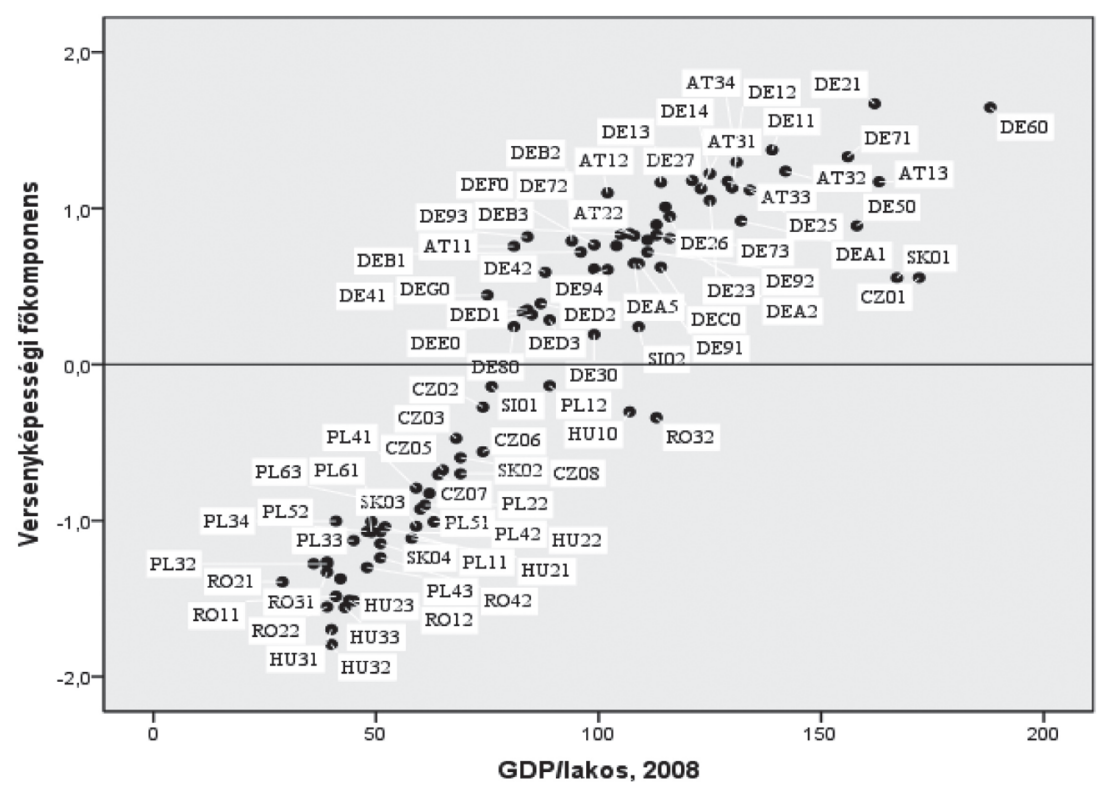

Forrás: Lengyel, Rechnitzer 2013, 112.

többi magyar régió viszont erősen leszakadt, a periferikus román és lengyel régiókkal megegyező értékekkel rendelkeznek.

A kutatás és fejlesztés faktor - kutatás-fejlesztési kiadások, high-tech szektorban foglalkoztattok aránya, állótőke-képződés, nyertes keretprogramok - a tudásalapú gazdaság és az innovatív szektorok jelenlétét szimbolizálja, ezek a tényezők már jobban szétterítik Kelet-Közép-Európa térségét. Ebben a „gombaalakot" követő megosztottságban a magyar régiók még látványosabban leszakadnak elsősorban a cseh, valamint a lengyel régióktól. Az elemzés újra megerősíti azt a magyar - de mondhatni kelet-közép-európai - sajátosságot, hogy a fóváros karakteresen elkülönül a többi térségtől - esetünkben Budapest -, s értékei jobban közelítenek a nyugat-európai térségekhez, közelebb állva a gomba „fejéhez”. A „törzsben” - mint leszakadó tömbben - található a többi magyar régió, jelezve azt, hogy kutatási-fejlesztési potenciáljuk kedvezőtlen, s ezzel versenyképességük is kimondottan gyenge Kelet-Közép-Európában.

\section{Trendek és irányok a kelet-közép-európai térszerkezetben}

A jelenleg is folyó kutatások alapján nem könnyü összegezni Kelet-Közép-Európa térfolyamatainak irányait, valamint a lehetséges fejlődési utakat. 
Az első megállapításunk az, hogy a nagyrégió országai és térségei egyre keményebb versenytérbe kerülnek, közöttük élesebbé válik a küzdelem, főleg a külföldi befektetések fogadásában, azok letelepítésében, a fövárosok és nagyobb regionális központok nyújtotta attraktivitásokban (szolgáltató intézmények, kutatás-fejlesztés, egyetemi képzési kínálat, nemzetközi szervezetek fogadása, turisztikai kínálat, vonzó környezet stb.). Ez a versenytér folyamatosan átrendeződik, újabb és újabb elemekkel gyarapszik, vannak újonnan feltörekvő országok és központok, mások kedvezőbb helyzetből indulva évek alatt versenyhátrányba kerültek, míg többeknél az elmozdulás csak lassabb, nem látványos.

A verseny tehát kiéleződött az országok között, mindez még jobban felismerhető a fövárosok esetében (Csomós 2011; Horváth 2007a). Megerősítést nyer az az európai tendencia, hogy a fơvárosok egyre nagyobb mértékben koncentrálják a jövedelmeket, hiszen mindegyik kelet-közép-európai fővárosban s annak régióiban a legmagasabb az egy före jutó GDP az országon belül, s ennek koncentrációja az időben előrehaladva egyenletesen emelkedik. Elmondható, hogy három fóváros az európai versenyben is kiemelkedik. Hiszen évek óta - változó helyezéssel - Pozsony, Prága és Bécs megtalálható Európa húsz legmagasabb jövedelmet termelő régiói között, de a feltörekvők között láthatjuk még Varsót, Budapestet, sőt Ljubljanát, valamint Zágráb és Belgrád is megjelenik ebben a sorban. Az európai metropoliszok versenyébe még nem szálltak be ezeknek az országoknak központjai (hogy ezek a fővárosok a nemzetközi szervezetek fogadásában, azok megtelepítésében akár nagytérségi, több országra kiterjedő, akár európai szerepet vívjanak ki maguknak), de nagyvárosi funkcióik, illetve az életminőséget illusztráló tényezőik kínálata egyre szélesebb, sokszínűbb (Csomós 2011).

Jellemzőnek tekinthető térszerkezeti sajátosság a fővárosi jövedelem és funkció, de a népesség koncentrációja mellett a szuburbanizációs folyamatok is felgyorsultak az ország központjai körül, sőt már a regionális centrumok övezetében is kimutathatók a népességtömörülési tendenciák. A fővárosok és néhány nagycentrum, regionális központ kínálja ugyanis a kedvező munkalehetőségeket, biztosítja az elérhető szolgáltatásokat, és egyben az életminőség alakításában is jobb feltételeket nyújt, így ezek a városok a belső migráció egyre határozottabb célpontjaivá válnak. Ennek ellentéte a kiürülő térségek egyre táguló földrajzi tere, az ottani népesség elöregedése, a csökkenő települési szintű szolgáltatások, a kedvezőtlen munkakörülmények, a hátrányos rétegek és csoportok megjelenése, majd egyes (nagy)terekben való koncentrációja. Mindezek az európai trendeket követik, de Kelet-Közép-Európa esetében ezek a trendek látványosabbak, sőt a leszakadó térségek egyre nagyobb tömbösödését még az országhatárok sem képesek megszakítani. A perifériák perifériái kirajzolódnak a nagyrégióban, s ezeknek a területi „fekete lyukaknak” a felszámolása vagy további terjedésének mérséklése jelentős forrásokat emészt fel, amit az országok többsége nem mindig képes vagy éppen nem akar előteremteni.

Az országok területi feltártsága, azaz például a főváros és a regionális központok összekapcsolása, gyors elérhetőségük biztosítása nem egyenletes, más 
és más hálózatfejlesztési filozófiát, majd gyakorlatot követtek az országok, így magának a nagyrégiónak a belső kapcsolatai is esetlegesek. Hiába léteznek európai távlati közlekedéshálózat-fejlesztési célkitűzések, csak lassan épülnek ki az úthálózatok, nem mindig a legkedvezőbbnek tartott irányokat vagy nem a centrumok elérhetőségét követve. Élénkülnek viszont az országhatár menti kapcsolatok, az átjárhatóság a határokon fokozatosan létrejön - gyengébben a periferikus térségekben. De ebben a térmetszetben is jelen van az élénkülő verseny, így nem ritkák a közeli regionális központok párhuzamos fejlesztései, a kapcsolatok elhanyagolása, az országon belüli igények megfeleléséhez rendelt projektek (pl. repülőterek, egyetemek, kutatás-fejlesztési bázisok, ipari-tudományos parkok stb.).

Sajátossága a nagyrégiónak, hogy az országok - s azok területi tervezői - még nem ismerték fel a fejlesztési koncepciók, tervek egymáshoz illesztésének, összehangolásának fontosságát. Így az egyes országok területfejlesztési koncepcióiban szigethatások érvényesülnek, nincs még Kelet-Közép-Európa dimenzióban - vagy akár a szomszédos, érintkező területek esetében sem - a térszerkezetre vonatkozó közös gondolkodás, de még annak az illúziója, kvázi intézményes keretei sem ismerhetők fel.

S végül, de nem utolsósorban szólni kell arról, hogy döntően a közép-európai (mag)régióban a jármüipar egyre jelentősebb szektorrá válik (Rechnitzer, Smahó 2012) (5. ábra). Nemcsak azáltal, hogy számos nagyvárosban megjelentek a járműipari, döntően személygépkocsi-összeszerelő üzemek, hanem, hogy velük párhuzamosan más európai gyártóközpontokat is ellátva megtelepültek a különböző szintű beszállítók, akár egy-egy nagyvárosban koncentráltan, akár kisebb-nagyobb településekben szétszóródva. A járműipari koncentrációk kedvező hatása több központban már érvényesül (oktatási-képzési kínálat, magasabb jövedelmek, beszállítók megjelenése, a szolgáltatások körének bővülése, szélesebb fogyasztási kínálat, növekvő bevándorlás, városi infrastruktúra fejlesztése stb.), de egyben e centrumok kitettsége (útfüggő helyi fejlődés) is fokozódik, amelynek oldására nem mindenütt figyelnek a fejlesztési elképzelésekben (Fekete 2015; Molnár 2012).

Tekinthetö-e Kelet-Közép-Európa egésze új európai fejlődési övezetnek? Az egész térség vélhetően nem lesz növekedési zóna, hiszen nem egységes, erősen megosztott, térszerkezetében elkülöníthető elemek, más és más jellegű növekedési központok, esetenként kisebb-nagyobb sajátos övezetek, zónák, magterületek ismerhetők fel, amelyek mellett ott vannak a mélyperifériák vagy a tartósan pangó, mozdulatlan terek, településhalmazok. A központok, elsősorban a fơvárosok szívóhatása jól felismerhető, mindez fokozza a területi különbségeket, az ellenpontok rendszerét. A verseny éles a fejlődési dinamikát mutató fővárosok és zónák között, ugyanakkor kezelni kellene az országokon belül kialakuló egyre látványosabb területi differenciálódást. Az országok gazdaság- és területpolitikája (már ahol van), még ha európai uniós elveket is követ, alapvetően eltér egymástól. Így aztán megvan az esélye, hogy egyes fővárosok és né- 
5. ábra: Járműipari központok Győr nagytérségében

Centers of automotive industry in the greater region of Györ

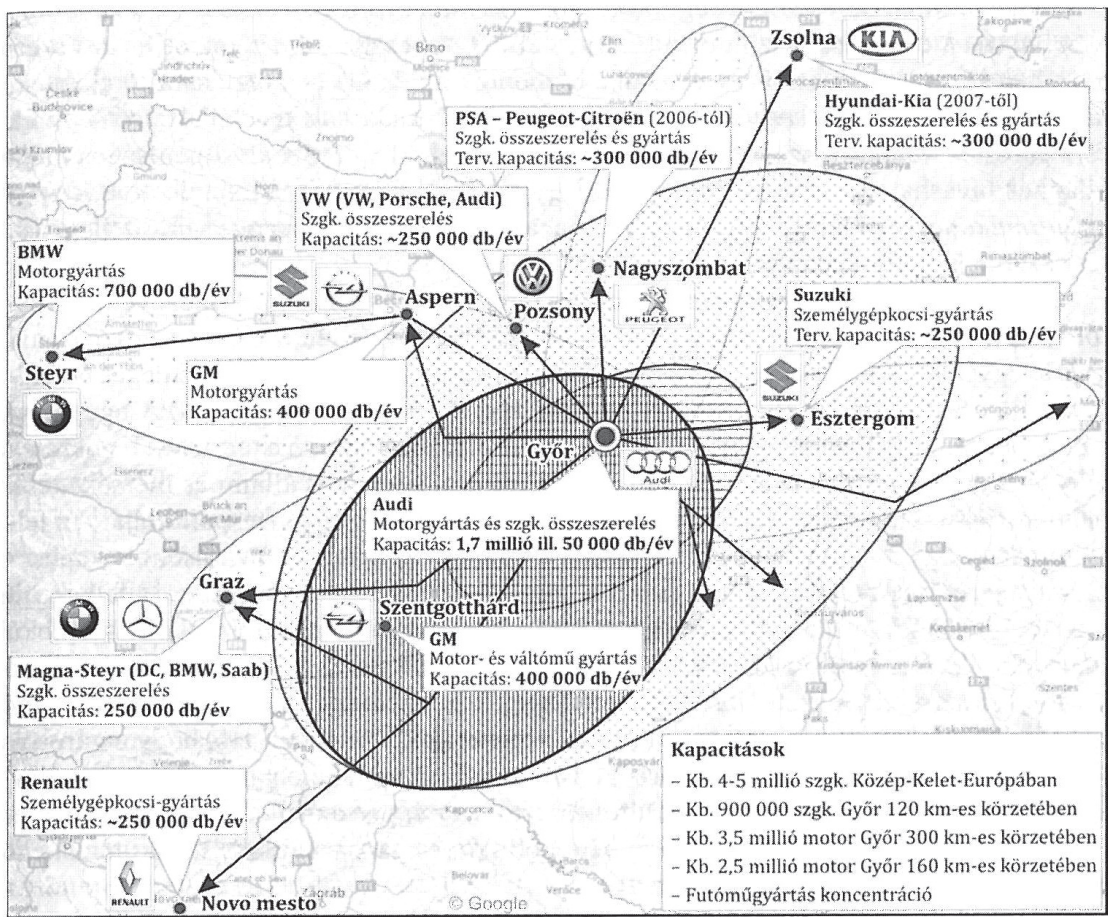

Forrás: Rechnitzer, 2016, 87.

hány regionális központ Európa izgalmas, jövőt hordozó erőközpontjává váljék, s másoknak meg arra van kilátásuk - talán éppen a politikai aktorok állhatatos törekvése ellenére is -, hogy a kontinens szegényházában maradjanak vagy oda sorolódjanak.

\section{Jegyzetek}

1 Horvátország és Szerbia vizsgálatba történő bevonásán is gondolkodtunk, hiszen e nyugat-balkáni országokkal a vizsgált országcsoportnak a történelmi, gazdasági, infrastrukturális és kulturális kapcsolatai erőteljesek és egymásra épülnek. A gondot az adatok és az információk elérhetősége jelentette, Horvátország esetében az európai uniós tagsággal (2013) jelentősen csökkent ez a probléma, míg Szerbia esetében a jövőbeli tagjelöltséggel szintén mérséklődhet.

2 Szabó Pál (2009) nagyszerüen végigveszi az európai térszerkezeti modelleket, azok különböző változatait (sokszögek, alakzatok), illetve a megnevezéseiket, azok változását, variációs lehetőségeit.

3 Ennél a modellnél még nem beszélhetünk Kelet-Közép-Európáról, hiszen a fentebb jelzett országok nem vagy csak nagyon érintőlegesen vannak jelen, de egyértelmüen megjelenik a térszerkezeti elemzésekben a kiterjesztés igénye és szükségszerüsége. 
4 Ennek az új iránynak a realitását az adja, hogy Lengyelország erősen törekszik az orosz vasúti szállítások fogadására, s ezzel a távolabbi ázsiai kapcsolat közvetítésére az Európai Unió magterületei felé.

5 A 25 változót hat csoportba rendeztük, így az általános jövedelmi helyzet (4 változó) mellett vizsgáltuk a kutatás-fejlesztés sajátosságait (5 változó), a humán tőke összetételét (5 változó), a működő tőke jellemzőit (1 változó), a traded szertorokat (2 változó), s a társadalmi tőkét és intézményeit (8 változó).

6 A frissebb regionális szintű GDP-adatok (2012) ezt az eredményt csak megerősítik, hiszen az Európai Unió 20 legfejlettebb régiói között hatodik a Pozsony régió (Bratislavský kraj), az uniós átlag 179\%-ával, s kilencedik a Prága régió (Praha), itt 172 \%-os eredményt mutattak ki. Bécs a 12. a sorrendben, s a 162\%-át hozta az EU-átlagnak. Budapestet is magában foglaló Közép-Magyarország tartósan a 96-98. helyen található, folyamatosan átlépve az EU-átlagértéket.

\section{Irodalom}

Brunet, R. (1989): Les villes „européennes”. Reclut/Datar, Paris

Csapó, T., Balogh, A. (eds.) (2012): Development of the settlement network in Central European countries. Past, present, future. Springer, Berlin, Heidelberg

Csomós Gy. (2011): A közép-európai nagyvárosok gazdaságirányító szerepe. Tér és Társadalom, 3., 129-140.

Ehrlich É., Révész G., Tamási P. (1994): Kelet-Közép-Európa honnan-hová? Akadémiai Kiadó, Budapest

Enyedi Gy. (1996): Regionális folyamatok Magyarországon az átmenet időszakában. Hilscher Rezső Szociálpolitikai Egyesület, Budapest (Ember, település, régió)

Enyedi Gy. (2010): Városok a közép-európai átmenetben. In: Barta Gy., Beluszky P., Földi Zs., Kovács K. (szerk.): A területi kutatások csomópontjai. MTA RKK, Pécs, 223-244.

Fábián A. (szerk.) (2011): Alkalmazott strukturális politikák Közép-Európában. Nyugat-magyarországi Egyetem Kiadó, Sopron

Fekete D. (szerk.) (2015): Nyugat- és kelet-közép-európai jármüipari térségek múködési modellje. UniversitasGyőr Alapítvány, Győr

Gorzelak, G. (1996): The regional dimension of transformation in Central Europe. Regional Studies Association, London

Horváth Gy. (1998): Európai regionális politika. Dialóg Campus Kiadó, Budapest, Pécs

Horváth, Gy. (2000a): Regional policy effects of the transition in East-Central Europe. Informationen zur Raumentwicklung, 7-8., 427-434.

Horváth Gy. (2000b): Decentralizáció és a régió - kelet-közép-európai nézőpontok. In: Horváth Gy., Rechnitzer J. (szerk.): Magyarország területi szerkezete és folyamatai az ezredfordulón. MTA RKK, Pécs, $60-73$.

Horváth, Gy. (2002): Regional policy and development in East-Central Europe. In: Domański, R. (ed.): Regions and cities in an enlarging European Union. Polish Academy of Sciences, Warsaw, 107-128.

Horváth Gy. (2004): A strukturális politika és a kelet-közép-európai régiók. Területi Statisztika, 3., 236-251.

Horváth Gy. (2005): A Kárpát-medence, mint az Európai Unió jövőbeli transznacionális makrorégiója: A közös kohéziós politika céljai. Közgazdász Fórum / Economists Forum, 9., 35-44.

Horváth Gy. (2007a): Régióközpontok Európában. Magyar Tudomány, 6., 704-720.

Horváth, Gy. (2007b): The dilemmas of creating regions in Eastern and Central Europe. In: Hajdú, Z., Illés, I., Raffay, Z. (eds.): Southeast-Europe: State borders, cross-border relations, spatial structures. Centre for Regional Studies of the Hungarian Academy of Sciences, Pécs, 72-98.

Horváth Gy. (2009): Regionális egyenlőtlenségek a kelet- és közép-európai kutatási térségben. Magyar Tudomány, 12., 1499-1512. 
Horváth Gy. (2010): Territorial cohesion in the Carpathian basin: Trends and tasks. Centre for Regional Studies, Hungarian Academy of Sciences, Pécs (Discussion Papers; 81.)

Horváth, Gy. (2012a): Regionalization in Eastern and Central Europe: obstacles and perspectives. Geography, Environment, Sustainability, 2., 4-17.

Horváth Gy. (2012b): Szempontok a kelet-közép-európai területfejlesztés megújításához az uniós változások tükrében. In: Bottlik Zs., Czirfusz M., Gyapay B., Kőszegi M., Pfening V. (szerk.): Társadalomföldrajz - Területfejlesztés - Regionális tudomány. ELTE TTK Földtudományi Doktori Iskola, Budapest, 85-100.

Horváth Gy. (2013a): A területi kutatásoktól a regionális tudományig. Kelet- és közép-európai tudománytörténeti vázlat. Tér és Társadalom, 4., 30-51.

Horváth Gy. (2013b): A kelet-közép-európai területi fejlődés két komponenséről. Közép-Európai Közlemények 1-2., 200-209.

Horváth Gy. (2014): Az új regionális fejlődési paradigma két eleme Kelet-Közép-Európában: intézményi decentralizáció és kutatás-fejlesztés. Erdélyi Múzeum, 4., 21-35.

Horváth, Gy. (2015a): Spaces and places in Central and Eastern Europe: Historical trends and perspectives. Routledge, London

Horváth Gy. (szerk.) (2015b): Kelet- és Közép-Európa régióinak portréi. Kossuth Kiadó, Budapest

Illés I. (2002): Közép-és Délkelet-Európa az ezredfordulón. Átalakulás, integráció, régiók. Dialóg Campus Kiadó, Budapest, Pécs

Kunzmann, K. R. (1992): Zu Entwicklung der Stadtsysteme in Europa. Mitteilungen der Österreichischen Geografischen Gesellschaft, 134., 25-50.

Kuttor D. (2012): Kelet-Közép-Európa változó gazdasági térszerkezetének modellezése. Miskolci Egyetemi Kiadó, Miskolc

Lengyel I. (2000): A regionális versenyképességről. Közgazdasági Szemle, 12., 962-987.

Lengyel I. (2012): Kelet-közép-európai térség régióinak versenyképessége. In: Rechnitzer J., Smahó M. (szerk.): Jármüipar és regionális versenyképesség. Széchenyi University Press, Győr, 126-158.

Lengyel, I., Rechnitzer, J. (2013): The competitiveness of regions in the Central European transition countries. The Macrotheme Review: A Multidisciplinary Journal of Global Macro Trends, 4., 106-121.

Lever, W. (1995): The European regional dimension. In: Lever, W., Bailly, A. (eds.): The spatial impact of economic changes Europe. Ashgate, Vermont, 178-203.

Lux G. (2009): Reindusztrializáció Közép-Európában. In: Fodor I. (szerk.): A régiók újraiparosítása. A Dél-Dunántúl esélyei. MTA Regionális Kutatások Központja, Pécs, 20-34.

Mezei C. (2006): Helyi gazdaságfejlesztés Kelet-Közép-Európában. Tér és Társadalom, 3., 95-108.

Molnár E. (2012): Kelet-Közép-Európa az autóipar nemzetközi munkamegosztásában. Tér és Társadalom, 1., 123-137.

Rechnitzer J. (1998): A területi stratégiák. Dialóg Campus Kiadó, Budapest, Pécs

Rechnitzer J. (2016): A területi tőke a városfejlődésben. A Győr-kód. Dialóg Campus Kiadó, Budapest, Pécs

Rechnitzer J., Smahó M. (2011): Területi politika. Akadémiai Kiadó, Budapest

Rechnitzer J., Smahó M. (2012): A jármü- és autóipar hatása a kelet-közép-európai térség versenyképességére. Magyar Tudomány, 7. (melléklet), 38-48.

Szabó P. (2009): Európa térszerkezete különböző szemléletek tükrében. Földrajzi Közlemények, 2., 121-134.

Szabó P., Farkas M. (2014): Kelet-Közép-Európa térszerkezeti képe. Tér és Társadalom, 2., 67-86.

Szabó P. (2015): Régió és térszerkezet az elmélettól a területpolitikáig. ELTE Eötvös Kiadó, Budapest

Szűcs J., Hanák P. (1986): Európa régiói a történelemben. MTA Történettudományi Intézet, Budapest (Előadások a Történettudományi Intézetben; 3.)

Tagai G. (2010): A városok szerepe a kelet-közép-európai országok térszerkezetének formálódásában. In: Barta Gy., Beluszky P., Földi Zs., Kovács K. (szerk.): A területi kutatások csomópontjai. MTA RKK, Pécs, 261-282. 